\title{
Humidity Sensor Characteristics of Porous Zeolite Ceramics at Elevated Temperatures
}

\author{
Masayuki NAGAI, Masayuki HIBINO and Tadashi NISHINO \\ (Musashi Institute of Technology, Tamazutsumi, Setagaya-ku, Tokyo 158)
}

\section{多孔質ゼオライトセラミックスの加熱時における湿度センサー特性}

\author{
永井正幸・日比野雅之・西 野 : 忠 \\ （武蔵工業大学, 158 東京都世田谷区玉堤 1-28）
}

\begin{abstract}
A commercial zeolite powder ( NaA type)was fired after pressing in pellet shape and the resulting samples were employed for electrical measurements. The impedances of the samples were measured at a fixed temperature ranging from $R . T$. to $400^{\circ} \mathrm{C}$ under various water vapor pressures. The impedance depended largely on the pressure and showed a significant hysteresis with a long response time during the measurement at $R . T$. On the contrary, its dependence on the pressure became less significant but exhibited substantially no hysteresis with a markedly short response time when heated at $400^{\circ} \mathrm{C}$.
\end{abstract}

[Received May 12, 1989; Accepted June 23, 1989].

Key-words : Humidity sensor, Zeolite, Porous ceramics, Hysteresis, Response time

\section{Introduction}

Various types of humidity sensors have been proposed and parts of them are commercially utilized. They are represented by electrolytes, ${ }^{1,2)}$ polymers ${ }^{3 / 4)}$ and porous ceramics. ${ }^{5)-9)}$ The main evaluation items of the sensors are durability against contamination, hysteresis, response time, operating temperature and humidity range and long term durability. In view of evaluation of humidity sensors, it is considered to be very difficult to meet these conditions exactly and those which fitted all of the above mensioned items have not been reported.

One of the ways to improve the sensor characteristics is to heat the sensor so as to accelerate the chemical reaction or physical state change. Although the humidity sensor characteristics of zeolite ceramics has been reported, ${ }^{10)}$ it is not examined in detail when it is kept at elevated temperatures. In the present study, the humidity sensor characteristics of porous zeolite ceramics at elevated temperatures are examined, with special emphasis on the improvement of the response time and hysteresis.

\section{Experimental}

Commercial zeolite powder (Tosoh Co. NaA 4 type $\left.\mathrm{Na}_{2} \mathrm{O} \cdot \mathrm{Al}_{2} \mathrm{O}_{3} \cdot 2 \mathrm{SiO}_{2} \cdot \mathrm{nH}_{2} \mathrm{O}\right)$ was employed as a starting material. After examined by thermal analysis and Scanning Electron Microscope (SEM), it was fired in the temperature range of $300^{\circ}$ to $1000^{\circ} \mathrm{C}$. The fired samples were examined by powder X-ray diffraction and SEM. The suitable firing conditions were determined based on the existing phases and microstructure.

About $0.4 \mathrm{~g}$ of the powder was uniaxially pressed in pellet shape with the dimension of $10 \mathrm{~mm}$ in diameter and $0.7 \mathrm{~mm}$ in thickness and fired at $500^{\circ}, 600^{\circ}$ and $700^{\circ} \mathrm{C}$ for 2 hours (Those fired at $500^{\circ}, 600^{\circ}, 700^{\circ} \mathrm{C}$ are denoted hereafter as S-5, S-6 and S-7, respectively). The resulting samples were attached to $\mathrm{Al}_{2} \mathrm{O}_{3}$ substrates with a ceramic bond after their both sides were painted with $\mathrm{RuO}_{2}$ as an electrode and connected with $\mathrm{Ni}$ lead wires. They were held in an oven at $100^{\circ} \mathrm{C}$ overnight, followed by heating up to $450^{\circ} \mathrm{C}$ and kept for 2 hours and cooled.

The impedances of the samples were measured at $1 \mathrm{kHz}$ using the same apparatus as described in the previous paper ${ }^{11)}$ except for the heating system. The sample was placed on an $\mathrm{Al}_{2} \mathrm{O}_{3}$ plate equipped with a tungsten heater (ceramic heater) which was maintained at prescribed temperatures by a digital temperature controller (E5T, OMRON Co. ). A sample holder made of quartz having the dimension of $8.5 \mathrm{~cm}$ in diameter and $6.5 \mathrm{~cm}$ in height was used for the electrical measurement. The relative humidity was maintained at a constant value by bubbling through saturated solutions $\left(\mathrm{NaCl}, \mathrm{CaCl}_{2}\right)$ or passing through $\mathrm{P}_{2} \mathrm{O}_{5}$ powder or distilled water. The actual relative humidity was monitored by a commercial humidity sensor (Scimarec Co. $\mathrm{SH}-\mathrm{S} 1)$. 


\section{Results and discussion}

\section{1 Sample preparation}

The phase development of the sample when it was heated up to $1000^{\circ} \mathrm{C}$ was examined by powder $\mathrm{X}$-ray diffraction. It retained the original crystal structure below $700^{\circ} \mathrm{C}$ while a different phase appeared above $800^{\circ} \mathrm{C}$. An endothermic peak at ca. $825^{\circ} \mathrm{C}$ observed in the DTA chart may be associated with the crystal structure change. The TG results indicated that weight loss, which is considered to be mainly due to water desorption, completed below $500^{\circ} \mathrm{C}$. The morphology change was also examined by SEM for the samples heated at various temperatures together with the as-received sample. The latter sample consisted of cubic-shaped particles with the dimension of 1 to $5 \mu \mathrm{m}$ in length. Substantially no change was found for the samples heated up to $700^{\circ} \mathrm{C}$, while the particle divided into smaller parts for those heated above $800^{\circ} \mathrm{C}$. The particle retained its original shape below $600^{\circ} \mathrm{C}$, while it became round at the edge of the cube above $700^{\circ} \mathrm{C}$.

\section{2 Humidity sensor characteristics}

Considering the phase development and the strength of the fired sample, those obtained in the temperature range from $500^{\circ}$ to $700^{\circ} \mathrm{C}$ were adopted for the electrical measurement. Figure 1 (a) and (b) show the relative humidity dependence for S-5, S-6 and S-7 measured at R. T. and $400^{\circ} \mathrm{C}$, respectively. The samples $\mathrm{S}-5$ and $\mathrm{S}-6$ exhibited similar behavior while S-7 showed largely different one. The difference may be associated with the fact that the crystal structure of the zeolite commences to reconstitute at ca. $800^{\circ} \mathrm{C}$ which is close to the firing temperature for S-7.

The relative humidity dependence for $\mathrm{S}-5$ at various temperatures is shown in Fig. 2. Comparing the impedance values at a fixed relative humidity in the high humidity region, the impedance at R.T. is lower than those at $100^{\circ}$ and $200^{\circ} \mathrm{C}$. According to reported dielectric relaxation measurement and nuclear magnetic resonance analysis results, it is suggested that the main charge carrier near R.T. would not be $\mathrm{Na}^{+}$but proton. ${ }^{12)}$ Considering the $\mathrm{TG}$ analysis results and the temperature dependence of the impedance in combination with the results in the literature, it is likely that the main charge carrier of the sample S-5 at R. T. would also be proton. It should be noted that the temperature does not directly reflect that of the atmosphere because only the surface of the sample is controlled at the prescribed temperatures with the ceramic heater. In view of the sensitivity, the preferred measuring temperature is R.T. or $100^{\circ} \mathrm{C}$. However, the
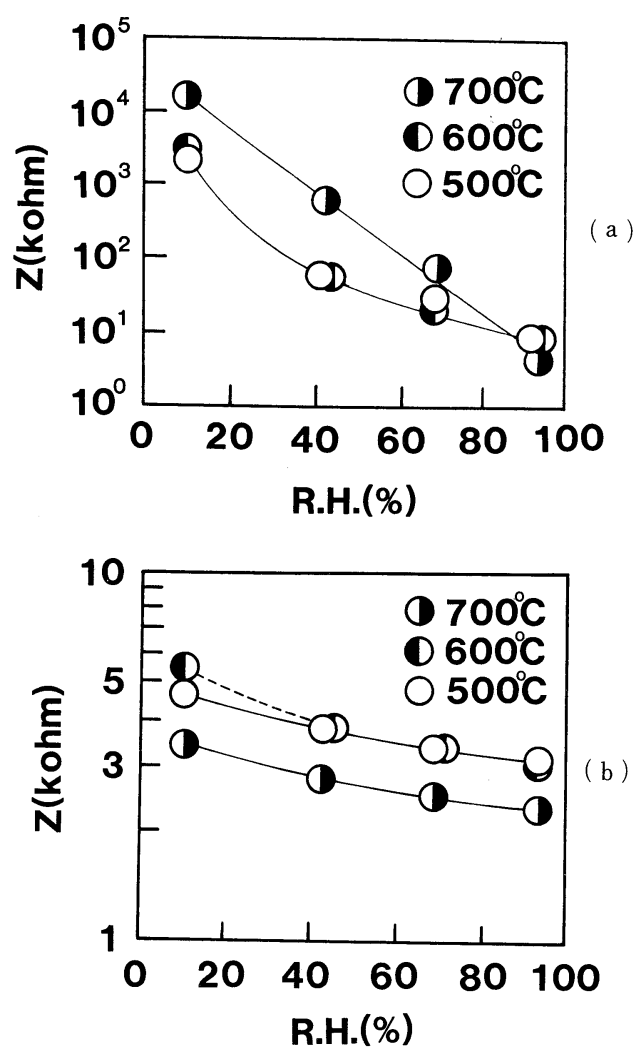

Fig. 1(a) and (b). Relative humidity dependence of the impedance at $1 \mathrm{kHz}$ for the samples $\mathrm{S}-5\left(500^{\circ} \mathrm{C}\right)$, $\mathrm{S}-6\left(600^{\circ} \mathrm{C}\right)$ and $\mathrm{S}-7\left(700^{\circ} \mathrm{C}\right)$ measured at R. T. (a) and $400^{\circ} \mathrm{C}(\mathrm{b})$.

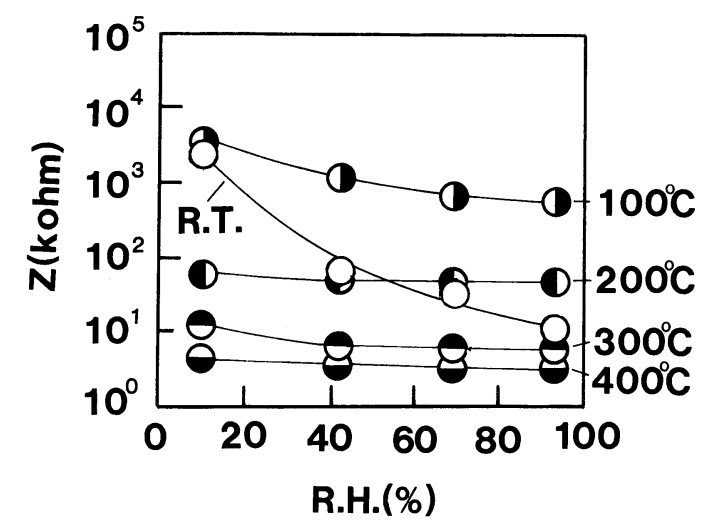

Fig. 2. Relative humidity dependence for the sample $\mathrm{S}-5$ as a function of measuring temperature.

impedance steadily and reproducibly depended on the relative humidity at more elevated temperatures.

Figure 3(a) and (b) show the hysteresis of the impedance for the sample S -5 at R. T. and $400^{\circ} \mathrm{C}$ respectively when the relative humidity was increased and subsequently decreased. The hysteresis is large at R. T. while that at $400^{\circ} \mathrm{C}$ is 

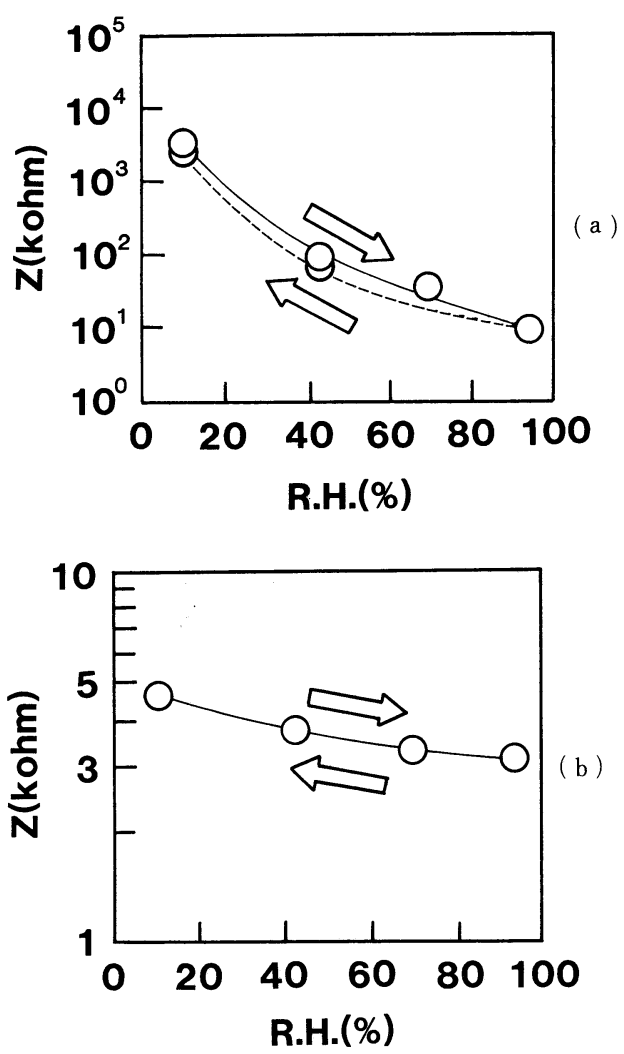

Fig. 3(a) and (b). Hysteresis of the impedance for the sample S-5 measured at R.T. and $400^{\circ} \mathrm{C}$ when the relative humidity was increased and subsequently decreased.

negligibly small. Since the impedance change at $R$. T. is related to the condensation process of the water vapor, it takes long time to reach an equilibrium state when the pore size is remarkably small as in this case. On the other hand, the impedance change at elevated temperatures cannot be explained by condensation process. According to a poposed model, polar molecules, such as water and ammonia, exhibit a strong association with most of mobile ions through ion-dipole interaction, which leads to decrease in the impedance in high humidity region. ${ }^{13)}$ If it is applicable to this case, the extremely small hysteresis at $400^{\circ} \mathrm{C}$ may be explained by acceleration of the reaction though detail of the mechanism is not clear at the moment.

One of the advantage for the sensor operating at elevated temperature is considered to be acceleration of the reaction, which may lead to reduction in the sensor response time. Comparison of the response time measured at $\mathrm{R} . \mathrm{T}$. and $400^{\circ} \mathrm{C}$ is summarized in Table 1. In every case, significant decrease in the response time is clear. Therefore, if the sensitivity of the sensor is large enough to
Table 1. Response time for the sample S-5 measured at R. T. and $400^{\circ} \mathrm{C}$ upon change in relative humidity.

\begin{tabular}{ccc}
\hline $\begin{array}{c}\text { Change in R.H. } \\
(8)\end{array}$ & $\begin{array}{c}\text { Measuring } \\
\text { R.T. } \\
90 \% \text { Response time (min) }\end{array}$ & $\begin{array}{c}400^{\circ} \mathrm{C} \\
\end{array}$ \\
\hline $\begin{array}{c}10 \rightarrow 42 \\
42 \rightarrow 10\end{array}$ & 7 & 4 \\
& 163 & 10 \\
\hline $42 \rightarrow 69$ & 11 & 5 \\
$69 \rightarrow 42$ & 60 & 5 \\
\hline $69 \rightarrow 93$ & 127 & 4 \\
$93 \rightarrow 69$ & 43 & 5 \\
\hline
\end{tabular}

determine the humidity when the sample is kept at elevated temperatures, measurement at such temperatures are preferable in terms of hysteresis and response time.

\section{Summary}

Porous zeolite ceramics was fabricated by firing the powder and examined in terms of humidity sensor characteristics at elevated temperatures. The following results are obtained.

(1) The suitable firing temperature for the zeolite powder is found to be in the range of $500^{\circ}$ to $700^{\circ} \mathrm{C}$ in view of the existing phase and the sample strength.

(2) Although the humidity sensitivity at $400^{\circ} \mathrm{C}$ was small comparing with that at $\mathrm{R}$. T., the hysteresis of the impedance at $400^{\circ} \mathrm{C}$ on increasing and subsequently decreasing the humidity became negligibly small.

(3) The response time could also be significantly reduced by heating the sample at $400^{\circ} \mathrm{C}$ comparing with that at R. T.

Acknowledgements The authors would like to thank Tosoh Co. for providing the zeolite powder. This study was partly supported by Nippon Sheet Glass Foundation for Materials Science.

\section{References}

1) F. W. Dunmore, J. Res. Nat. Bur. Std., 20, 723-44 (1938).

2) Y. Yamada, Denshi-Gijyutsu, 21, 26-30 (1979).

3) M. Hijikigawa, S. Miyoshi, T. Sugihara and A. Jinda, Sensors and Actuators, 4, 307-15 (1983).

4) S. Sakurai, Sensa-Gijyutsu, 2, 175-77 (1982).

5) R. T. Johnson, Jr. and R. M. Biefield, Mater. Res. Bull. , 14, 537-42 (1979).

6) Y. Shimizu, H. Arai and T. Seiyama, Denki Kagaku, 50, 831-34 (1982).

7) B. M. Kuiwicki, J. Phys. Chem. Solids, 45, 1015-31 
(1984).

8) N. Ichinose, Am. Ceram. Soc. Bull., 64, 1581-85 (1985).

9) T. Nitta, Ind. Eng. Chem. Res. Develop., 20, 669-74 (1981).

10) Y. Shimizu, H. Arai and T. Seiyama, Denki Kagaku, 53, 300-05 (1985).
11) M. Nagai and T. Nishino, Sensors and Actuators, 15, 145-51 (1988).

12) H. Takahashi, "Zeolite and Its Application" (in Japanese), Gihodo, Tokyo (1967) pp. 44-50.

13) D. N. Stamires, J. Phys. Chem., 36, 3173-81 (1962).

\section{訂 正}

日本セラミックス協会学術論文誌 97 [8］ 803-11（1989）掲載の, 荒戸利昭・中村浩介 . 祖父江昌久 “多孔質 $\mathrm{Al}_{2} \mathrm{O}_{3}$ 焼結体の耐熱衝撃特性”の本文中に誤りがありましたので，以下の ように訂正します.

\begin{tabular}{|c|c|c|}
\hline 目 & 誤 & 正 \\
\hline $\begin{array}{l}\text { 本文 } 809 \text { ページ } \\
\text { 左段 } 3 \text { 行め }\end{array}$ & $\begin{array}{l}\sim 1.30 \mathrm{~mm} \text { と報告している. } \\
\text { 実測值の精度が....... }\end{array}$ & $\begin{array}{l}\sim 1.30 \mathrm{~mm} \text { と報告している } \\
\text { (表 } 5 \text { ). 実測值の精度が....... }\end{array}$ \\
\hline $\begin{array}{l}\text { 本文 } 810 \text { ページ } \\
\text { 左段 } 7 \text { 行め }\end{array}$ & 表 5 & 表 6 \\
\hline $\begin{array}{c}\text { 本文 } 810 \text { ページ } \\
\text { 左段 } 14 \text { 行め }\end{array}$ & 表 6 & 表 7 \\
\hline
\end{tabular}

日本セラミックス協会学術論文誌 97［8］ 864-67（1989）揭載の，渡 孝則・秋月俊彦・ 池田博志・鳥飼紀雄・松田應作 “ $\mathrm{AlCl}_{3} \cdot \mathrm{NH}_{3}-\mathrm{NH}_{3}-\mathrm{N}_{2}$ 系気相反応により合成した AlN 粉体の 形態”の本文中に印刷上の手違いがありました，下記のように訂正し，お詫びします.

本文 867 ページ左段（上から）2 行めの後に, 同ページ左段（下から）1行めから右段（上 から） 1 行めが移動します.

日本セラミックス協会学術論文誌 97 [ 9] 916-22（1989）掲載の, 土谷敏雄・山城一秀・ J.D. Mackenzie “ディップコーティング法によるマグネトプランバイト型フェライト薄膜の 作製亡磁気的性質”の本文中に印刷上の手違いがありました，下記のように訂正し，お詫びし ます。

本文 916 ページ左段（下から）1 行めの後に, 同ページ右段（下から）1 行めが移動します. 